\title{
An Advantage of Digital Book for Business Education in Indonesia Country
}

\author{
*Dhani Ariatmanto, Rizky \\ STMIK Amikom Yogyakarta, Indonesia \\ *dhaniari@amikom.ac.id
}

\begin{abstract}
The main objective of this paper is to see the opportunity of a business education about digital book that consist of media education in Indonesia country. As we know the technology of a digital book for multimedia learning are still rare use by Indonesia educational teachers, the purpose is to determine the profit business in the future for making of digital book. The research design consisted of development design. The methodology analysis that will use in this research is SWOT (Strength, Weakness, Opportunity, Threats). The result of a research is finding that the business of digital book for learning tools in Indonesia country still open wide. Recommendations have been given on the basis of findings.
\end{abstract}

Keywords: Digital book, Indonesia country, multimedia learning, learning tools, business.

\section{Introduction}

The design of multimedia-based interactive media with all its advantages are expected to overcome the various obstacles faced education in Indonesia. Interactive media is the integration of digital media including combinations of electronic text, graphics, moving images, and sound, into a structured digital computerized environment that allows people to interact with the data for appropriate purposes. The digital environment can include the Internet, telecoms and interactive digital television (Elaine \& Andy, 2011). Some constraints in the face is, at time of indirect materials is learning knowledge use print and hardcopy media is usually less clear the picture knowledge. The rapid advancement of technology today is very versatile computerized effect on brain development, be it positive or negative. Look on the bright side we can utilize these technologies to create an interactive learning media to increase interest in children's learning. Because one of the old methods likes seeing normal images without animation or with real props are less than the maximum and interesting for the kids. Teaching and learning process will be more interesting and exciting because in the multimedia are combining element of text, images, audio, video, and animation, which was made into a media that is easily digested and understood by student.

Using this technology, the author make learning application media based interactive multimedia about knowledge. In this digital book, there are materials and exercise, so they can measure how much their ability to understand and absorb the materials that has presented. With this learning media, it is expected that student's can more quill understand and improve their enthusiastic in study. By improving the quality and the quality of early childhood education, would be much better if the old method coupled with current learning methods that completely computerized, easy to use, more attractive to children and can be applied as a tool in teaching and learning activities. Instructional media presented in a multimedia package that used to make the learning process can now be done monotonous interactive and interesting. Output of this multimedia education is digital book that compatible with Smartphone, tablet, and PC. An e-book is "any content that is recognizably 'book-like', regardless of size, origin or composition, but excluding journal publications, made available electrically for reference or reading any device (handheld or desk-bound) that includes a screen" (Armstrong, 2008). 


\section{Methodology}

Table 1: SWOT Analysis

\begin{tabular}{llll}
\hline Opportunities & Threats & Strengths & Weakness \\
\hline Massive mobile market at & Payment gateway & Great learning progress & Low adapting technology \\
Indonesia & Infrastructure & Interactive media & among teacher \\
Integrated advertising & problem & Low Cost & Long editing process \\
\hline
\end{tabular}

Procedure of computer-based learning software products by Chadwell $(2009,8-14)$ is as follows:

- Concept

- Design

- Material collecting,

- Assembly

- Testing.

- Distribution

E-Book Types: As e-books move further away from conveying a story or content in the way print-based books do, we may well ask at what point is an e-book really no longer a book but something else? Our traditional concept of content consumption is changing because of technology, which will ultimately have a profound impact on the concept of a book as new generations of readers mature and gravitate to new technologies (Nelson 2008, 44). As in the traditional print book market, there are several different types of ebooks currently being published. In general, the forms that an e-book can take are familiar: reference, textbook, monographs in series, and the more traditional or standard monograph. Where e-books diverge from their print counterparts, however, is in the distinction between these forms. The lines between the types of e-books are more blurred than with print books, which can be either attractive or troublesome. Furthermore, the lines are blurred between e-books that appear to be monographs and those that more closely mimic other electronic material such as e-serials and databases.

Digital publishing business models: Digital publishing business model can be used as a planning and management to determine the right strategy to develop a model of digital books in Indonesia. Without an understanding of these strategies, it will be difficult to develop products that match the requirements of a region in the country of Indonesia. The pattern of territory includes language, habits and interests to shape the implementation of digital books have become important factors in look, that the content of the digital book can be well understood and demand by the public. Implementation of cooperation with the government as a regulator of education in Indonesia and private companies in the field of smart phone products can also be used as a business strategy in developing the application of digital books. Suppose the company that developed the smart phone application digital books can be embedded in a package with the purchase of smart phone so it can appeal to the buyer. With the implementation of sustainable business, the digital books that have been pinned in the smart phone can continue to be the need for users and company can offer additional content of the material with purchased at low prices, why it's cheap? Because buyers do not have to buy an entire chapter just on some chapters they need. Other advantages that the material is not tangible like a book so durability is maintained.

In the literature reviewed, the document with a typology of business models for publishing is the report prepared for the Joint Information Systems Committee published on 2009 (Houghton \& Charles, 2010). These models are within the context of research communication evolution. The types of models are:

a) Subscription, this model is typical of prints, considering document availability it has been present in paper-view plans.

b) Hybrid/transition: a mix of business models with 2 alternatives, access is opened after a period of time of the document being published and access is opened according to the author's decision.

c) Open access: this has two kinds, on one hand there are open access journals and on the other hand there are open access files obtained through databases. In this case, several services overlap: overlapping publications, peer review services, index and summaries, quality control evaluation, a new file analysis, new metrics evaluation, warning services, etc. 


\section{Digital publishing in Indonesia Country}

- Until now, eBook sales have only made up about 2\% of total turnover. Not all publishers have started publishing eBooks, not least because of the omnipresent piracy challenge. Most people read on tablets rather than e-readers. Persona Edu now produces an eBook reader (tablet) together with Gramedia.

- With a growing middle class, education is becoming more and more important. Indonesia's youth are very digitally minded, and the country has the third largest facebook and twitter communities worldwide.

- In 2013 there were c.63 million social media users, and about 45\% of the population used mobiles to read and study. In 2006 the ministry of education planned to make digital textbooks available all over the country, and it went on to produce it sown teaching material. This resulted in a fiasco, and some publishers of the original textbook send up printing the digital material as the (often poor) schools were unable to use it. Teaching of e-learning is mandatory.(source : frankfurter buchmess international book exhibition 14 - 18 October 2015)

By December 2012, the iTunes Store had been made available in 119 countries, with Hugh markets such as India and Indonesia, Russia, Saudi Arabia and Turkey being able to access an online market place for music and various other digital content. (Apple press release, 4 December 2012). By late summer 2013, claims to have sold eBooks from its catalogue of 3.5 million books and magazines into 190 countries, with its devices supporting 68 languages. As of September 2013, Kobo has expanded beyond Canada, where in 2012 it controlled a market share of $46 \%$, according to IPOs, by establishing localized platforms in Brazil, France, Germany, Indonesia, Japan, the Netherlands, Portugal, South Africa, Thailand, Taiwan, UK, and the US. Rakuten's CEO Hiroshi Mikitani has been quoted that Kobo was the market leader for eBooks in France. (Forbes, 6 September 2012).

\section{Results and Discussion}

Business education for digital book have a huge opportunity in Indonesia country, this can be seen from the development of the population of a country compared to other countries. Indonesia is the third largest Asian nation it shown by table 2 .

Table 2: Comparative indicators for selected Asian nations

\begin{tabular}{|c|c|c|c|c|c|c|}
\hline Nation & $\begin{array}{l}\text { Total } \\
\text { surface } \\
(' 000 \mathrm{~km} 2)\end{array}$ & $\begin{array}{l}\text { land } \\
\text { area } \\
\end{array}$ & $\begin{array}{l}\text { Total } \\
\text { Population( } \\
\text { 2013) } \\
\end{array}$ & $\begin{array}{l}\text { Average annual population } \\
\text { growth rate } 2008-2013\end{array}$ & $\begin{array}{l}\text { Population } \\
\text { density } \\
(2012)\end{array}$ & $\begin{array}{l}\text { Age } \\
\text { dependency } \\
\text { ratio(2012) }\end{array}$ \\
\hline China & 9597 & & 1361 & 0.5 & 142 & 36 \\
\hline India & 3287 & & 1233 & 1.3 & 131 & 53 \\
\hline Indonesia & 1905 & & 249 & 1.5 & 131 & 52 \\
\hline Korea & 100 & & 50 & 0.5 & 503 & 37 \\
\hline Malaysia & 331 & & 30 & 1.7 & 91 & 47 \\
\hline Pakistan & 796 & & 184 & 2.1 & 232 & 63 \\
\hline Philippines & 300 & & 97 & 1.5 & 325 & 62 \\
\hline Singapore & 0.7 & & 5 & 2.2 & 7540 & 36 \\
\hline Thailand & 513 & & 65 & 2.4 & 126 & 39 \\
\hline Vietnam & 331 & & 90 & 1.1 & 271 & 42 \\
\hline
\end{tabular}

Source: Asian Development Bank, Basic Statistics 2014.

The distribution of the age for Indonesian population in 2014 according the UNFPA (United Nations Population Fund) has projection Indonesian population as show by table 2.

Table 3: Age composition of the Indonesian population, 2014 estimate

\begin{tabular}{lllllll}
\hline Nation & $\begin{array}{l}\mathbf{0 - 1 4} \\
\text { years }\end{array}$ & $\begin{array}{l}\mathbf{1 5 - 2 5} \\
\text { years }\end{array}$ & $\begin{array}{l}\mathbf{2 5 - 5 4} \\
\text { years }\end{array}$ & $\begin{array}{l}\mathbf{5 5 - 6 4} \\
\text { years }\end{array}$ & $\begin{array}{l}\text { 65 } \\
\text { over }\end{array}$ \\
\hline $\begin{array}{l}\text { Percentage in each age } \\
\text { group }\end{array}$ & 27.6 & 17.2 & 42.8 & 7.2 & 5.3 & and \\
\hline
\end{tabular}


From the data tables above show that there are opportunities, why? If population associated with the use of technology, especially mobile applications how much the use of the technologies of the everyday life can be show by figure 1 .

\section{Figure 1: Technology use in Indonesia for Internet}

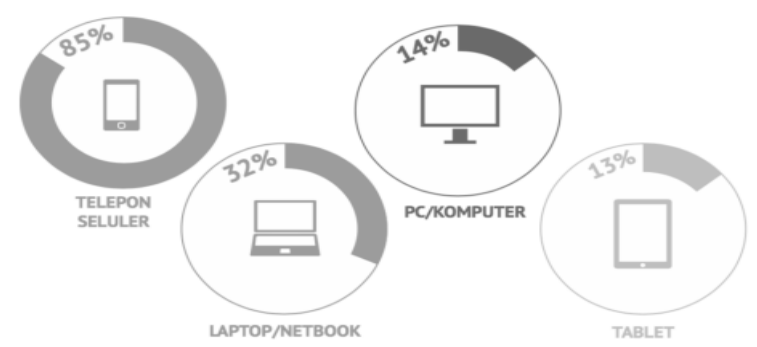

Source: APJII, Profile Internet Indonesia, 2014

Associated with it through Presidential Decree No. 96 of 2014 on the Broadband Plan 2014-2019 Indonesian government is targeting $30 \%$ of the population in urban areas can enjoy broadband internet in 2019 . While in the countryside, the target of broadband penetration will reach $6 \%$. Of the development plan, the government expects the price of broadband services can reach $5 \%$ of total revenue per capita (Rüdiger, 2014). That is, this is an opportunity for businesses in a variety of telecommunication industry.

Digital Book for Business in education: Digital book for business education need special treatment that involve support from government, education institution, and parent to apply the use of digital book for class learning, why? Digital book can be constructed and customized accordance with the requirements. Content for digital book in education can be manage for targeting the level education for the student, choose for the content is flexible for:

- Content can produce like a game education with fun graphic and minimal text

- We can provide some exam, practice and simulation so it can interact with the student more collaborative.

- Customize for the material content such media text, graphic, video, animation like 2D or 3D and sound is limitless.

Value of Proportion Digital Book: There is a proportion of the value of building a digital book for developers and for users

- Zero Installation

- Interactive

- Easy Build

- Great Design

- Low Price

- Adorable \& portable

- Massive Distribution

- Updatable

Table 3: Profit Analysis Business of Digital Book

\begin{tabular}{ll}
\hline Profit Analysis & \\
\hline TARGET MARKET & 23.000 .000 \\
\# of leads & 10.000 .000 \\
\% conversion rate & $10 \%$ \\
COSTUMER & \\
Average sale & Rp. $50.000,-$ \\
\# of transaction & 5 \\
REVENUE & Rp. 250.000 .000 \\
\% margin & $25 \%$ \\
PROFIT & Rp. 62.500 .000 \\
\hline
\end{tabular}


Business Calculation: This is just an example for the calculation in business education for digital book. Let' subscribed amount the total market tilled 23 million customers spread from primary school students to students and teachers researchers. Target only affordable related to technology availability in 2015 only 10 million subscribers. But in the first year, the company only targeting $10 \%$ of the market that are affordable. So that the carrying amount of costumer as many as 1000 people. With an average income of price of digital books Rp. 50,000, with a repeat order as much as $5 x$ the amount was reached Rp. 250,000,000. If cut with a margin of 35\% then the benefits are Rp.62.500.000 (millions) it shown by table 3 .

\section{Conclusion}

There is a huge opportunity for business education in digital book, with a good management between government, institution and developer it will be a massive income in the other hand we support for global green environment. Reduction in the use of paper by changing the pattern of the community to better utilize digital book technology in everyday life helped preserve nature. Provides an insight into the use of digital technology in a more positive context is not just an entertainment.

\section{References}

Armstrong, C. (2008). Books in a virtual world: the evolution of the e-book and its lexicon. Journal of Librarianship and Information Science, 40, 193-206.

Chadwell, F. A. (2009). What's next for Collection Management and Managers? User-Centered Collection Management. Collection Management, 34(2), 69.

Elaine, E. \& Andy, F. (2011). Interactive Media - What's that? Who's involved? ATSF White Paper-Interactive Media UK-(C)2002/2011.

Frankfurter-Buchmesse (2015). International book exhibition 14-18 October 2015 Retrieved from http://www.buchmesse.de/images/fbm/dokumente-ua pdfs/2015/book_market_indonesia_ 52246.pdf

Houghton, J. W. \& Charles, O. (2010). The economic implications of alternative publishing models. In: Prometheus: Critical Studies in Innovation, 28(1), 41-54.

Nelson, M. R. (2008). E-books in Higher Education: Nearing the End of the Era of Hype? EDUCAUSE Review, 43 (2).

Rüdiger, W. (2014). Global eBook: A report on market trends and developments OECD/Asian Development Bank (2015), Education in Indonesia: Rising to the Challenge, OECD Publishing, Paris. http://dx.doi.org/10.1787/9789264230750-en. 